\title{
EPISTEMIC ENCOUNTERS: SOCIAL SCIENCES AND THE RETHINKING OF URBAN PLANNING POLICIES IN THE EARLY 1970S ROMANIA
}

\author{
MARA MARGINEAN 1
}

\begin{abstract}
This article aims to conduct a case study on urban planning models drawn by social scientists in 1970s Romania. It looks at the trans-national channels of knowledge circulation and reconstructs specialists' role in creating new bridges of cooperation between the first and second world. It also analyzes the gradual re-signification of these ideas locally as part of the socialist state development project. More precisely, it wants to answer three intertwined questions: To what extent did the trans-nationalization of knowledge in the late 1960s determine a particular approach to urban planning in Romania? What does this tell us about local professional practices' autonomy? Which was the international relevance of Romanian social sciences' practice? The article contributes to an emerging scholarship on the genealogy of these ideas by placing the transnational debates of the late 1960s and early 1970s consumed under the umbrella of various international organizations, such as the ISA and the UN, in conversation with an intellectual tradition dating back to the interwar period.
\end{abstract}

Keywords: social sciences; urban planning; transnational; knowledge production; the 1970s Romania

\section{Introduction ${ }^{2}$}

The main aim of the Eighth World Congress of Sociology, held in Toronto in 1975, was to analyze "the degree of activism that sociologists must show in their professional practice" (ANIC, fund ASSP-Sociologie, file 6/1972, p. 34). This ambitious goal was tellingly outlined by Congress's central theme: "Science and Revolutions in Contemporary Societies." The event brought together social scientists from around the world, who were keen to debate their

1 Senior researcher at George Baritiu Institute of History, Cluj-Napoca, email: maramarginean@yahoo.com.

2 Research for this work has been conducted as part of a research grant financed by UEFISCDI, project code PN-III-P1-1.1-PD-2016-1462. 
professional status and the political relevance of their practice. From many points of view, the gathering provided an excellent opportunity for trans-national and trans-ideological professional debates between practicians from the first, the second, and the third world countries. However, it soon became apparent that such a plan was complicated by the large number and the diversity of the participants' intellectual and ideological backgrounds. For example, in a letter sent to Miron Constantinescu in 1974, Reuben Hill, president of the International Sociological Association, expressed his reservations about the Romanian expert's proposal's relevance for the Congress' theme. Entitled "The Role of the Sociologist: Observant or Participant?" Constantinescu's paper looked at social scientists' involvement in Romania's decision-making processes from the 1920s until the 1970s. Although informative from a Marxist viewpoint and somehow aligned with the 1970s international sociology interest in addressing social inequalities and poverty, Constantinescu's contribution allegedly failed to place the Romanian case in conversation with global social shifts. It also lacked theoretical innovation. Hill claimed that the paper eluded the international scientific community's current effort to address social reform as a transnational project relevant for both the developed and developing (semi)global peripheries (ANIC, fund ASSP - Sociologie, file 34/1973, p. 5). In his reply, Constantinescu admitted Hill's critique's rightness and promised to revise and resubmit an improved version of his paper. Unfortunately, Constantinescu died in July 1974 before having the chance of resubmitting his paper. However, the letter exchange between the two is meaningful from at least two points of view. On the one hand, it fleshes out the global dimension of sociological knowledge in the 1970s. On the other hand, it outlines a vast analytical space where the distinct meanings of activism and professional autonomy in various politicalideological contexts came to life.

Significant studies have shown that already by the late 1960s, social scientists' voice was increasingly important in policy-making processes around the world (AONU Geneva, box 2058). After decades when scientific knowledge was used extensively in the ideological confrontation between the two blocs,

scientists began to try to transcend the Cold War by embracing a transnational, rather than bipolar, view of scientific internationalism, one based on the ideals of science in itself, rather than on geopolitics (Rubinson, 2012: 248).

These trends led to the emergence of new trans-national epistemic contexts, where technocratic thinking became actively involved in improving nationstates' governing acts (Lorenzini, 2004: 90; Jolly et al., 2004: 111-2). Through 
such an intellectual effort, researchers highlighted the interconnections between various parts of the globe as manifestations of the late 1960s industrial society's crisis (Ferguson, 2010,3). Recent research has shown the multitude of ways in which individuals in the West and East perceived generational change, increased consumption, or flexibilization of capital after 1968 (Iriye et al., 2012; Murphy, 2006; Pula, 2018; Mark et al., 2019). However, little is known about the processes of transnational co-production of knowledge and the mechanisms for converting it into public policy in the East-Central European (semi)periphery, and even less about the similarities and differences between East and West regarding the experts' agency and their visibility in policy-making processes.

This article aims to fill this gap by conducting a case study on urban planning models drawn by social scientists in 1970s Romania. It looks at the trans-national channels of knowledge circulation and reconstructs specialists' role in creating new bridges of cooperation between the first and second world. It also analyzes the gradual re-signification of these ideas locally as part of the socialist state development project. More precisely, it wants to answer three intertwined questions: To what extent did the trans-nationalization of knowledge in the late 1960s determine a particular approach to urban planning in Romania? What does this tell us about local professional practices' autonomy? Which was the international relevance of Romanian social sciences' practice?

In Romania, the first reliable studies on urban planning belong to Cincinat Sfințescu. An engineer by training, he was appointed chief architect of the city of Bucharest in the 1930s. In that capacity, he drew the first systematization plan of the capital city, making a case for social, cultural, and economic integration of rural peripheries into its urban structure. However, his views had only a limited impact on his contemporaries. The national decision-making factors' lack of interest may be an illustration of the country's economic specificity. According to the official data, in 1938 , more than $80 \%$ of the population lived in villages on the brink of subsistence, making any project of urban development little relevant.

Furthermore, as most researchers noted, the 1930s stood out as a complicated intellectual context; the monographic school of Dimitrie Gusti - that is the intellectual nucleus of modernization in interwar Romania, had imagined sociology as a "scientific discourse" about an eminently rural nation (Rostaș, 2000). After 1948, with the coming to power of the communist regime, Sfințescu's ideas were re-signified. In the late 1940s, the Ministry of Construction commissioned Henry Stahl and several other sociologists trained in the interwar period to conduct monographic research of the Hunedoara industrial region and draw up a draft for territorial development (Mărginean, 2015). Subsequently, almost two decades later, territorial planning reappeared at the forefront of the public 
agenda as soon as political leaders announced a major national-communist development project. These temporal and intellectual interconnections came to life due to Miron Constantinescu and Henry Stahl's vigorous activity, two Marxist sociologists trained at Dimitrie Gusti's Interwar School, who reached their professional maturity after 1945 . While the former served as chairman of the State Planning Committee in the early 1950s (Bosomitu, 2015), the letter dedicated most of his professional life to research and higher education (Guga, 2015).

Drawing on documents from the Archives of the United Nations in Geneva and the Romanian National Archives in Bucharest, this article aims to integrate national urban thinking into a broader discussion about city renewal that surfaced in the 1970s international expert community. I premise that unlike diplomatic cooperation between states, which evolved according to geostrategic thought-through procedures, conversations between scientists followed specific paths, being often informal and personal. Moreover, intellectual affinities may have been articulated on generational and ideological grounds, making professionals the main vectors of global scientific knowledge's production and circulation. When considering the letter exchange between Hill and Constantinescu from this angle, one could foresee the multiple possibilities of cross-fertilization of ideas of two experts trained in the interwar period, who happened to get acquainted when the international community reconsidered the social sciences' part in social reform and the global stakes of these processes. Accordingly, despite unquestionable pragmatic implications, the 1970s scientific cooperation between the first, the second, and the third world countries echoes a line of thinking that originated in the interwar period when East-European was considered a laboratory of global development projects. However, as this article will show, the entanglement of these intellectual paths "at the edge" of the international knowledge field also carried ambiguous national outcomes. Although it determined the emergence of a new institutional logic in Romania, it also increased experts' self-awareness as "agents of modernization" every time the socialist state's decision-making process was at stake. Their internationalism channeled and even facilitated national communism (Cotoi, 2011; Hâncu and Karady, 2018). The forms of activism visible in professional circles, especially taking forms of assimilation transposition of allogeneic ideas into vectors of state planning and regulation of the economic activity.

\section{Sociology under state socialism}

In many ways, sociological approaches to urban space mirrored the social sciences' status during the communist regime. Cataloged as a bourgeois, reactionary, anti-scientific, and obscurantist discipline by the authorities, sociol- 
ogy was banned in 1948 when the Romanian state adopted some legislative initiatives regarding the reorganization of university education. Building on the discursive framework of the Soviet Union, the leaders of Bucharest sought to impose Marxism-Leninism and scientific socialism as an interpretive system of contemporary social realities (Bosomitu, 2014: 334-340).

Similar measures have been taken in the other socialist states. In some countries, such as Bulgaria or Hungary, where sociology had been a minor scientific field in the interwar period, the models outlined by Soviet ideologies could be more easily assimilated. In others, such as Romania, Poland, and Czechoslovakia, however, where the 1930s were very fruitful in terms of sociological research, the post-1948 constraints had not only methodological but also professional implications. In Romania, for example, many of the specialists were imprisoned or went into exile. However, a few continued their activity under the umbrella of other disciplines such as folklore, economics, or statistics (Dobos, 2020).

In the conditions of the ideological thaw produced after Stalin's death, the latter's expertise played an essential role in the discipline's revival. Building on the methodology of monographic research, finalized in the interwar period by Dimitrie Gusti's School, the campaigns carried out by the new institutes of the RPR Academy aimed at analyzing social processes in factories, urban areas, and rural communities. As the number of scientific productions increased, decision-makers' actions to give institutional consistency to sociology became numerous. Political involvement allowed the establishment of the National Council of Sociology in 1959 and the initiation of steps to resume ties with the international community by joining the International Sociological Association in the same year. In 1964, another political act established the re-institutionalization of sociology by setting up research centers in universities and assuming specific national research programs (Bosomitu, 2014: 339).

These measures have allowed an unprecedented development of the profession. During the 1960s, the number of sociological productions increased explosively. This intellectual effervescence was doubled by expanding the research infrastructure in Bucharest and other university centers in the country. The perpetuation of the Gustian tradition had some apparent advantages. Focusing on analyzing reality "as it exists" meant prioritizing empirical research on rural areas and socio-economic regions. The focus was on "classical" sociological processes such as modernization, industrialization, or urbanization. Unlike the so-called socialist sociology practiced in Romanian philosophical circles, especially in the 1950s, the empirical sociology of Gustian inspiration had a critical "atheoretical, predominantly descriptive" dimension (Zamfir \& Filipescu, 2015: 118). Equally, because of the new institutional framework in 
which the discipline was developed, some methodological adjustments were outlined. The research of the 1960s benefited from students' massive involvement in research campaigns; the analyses were carried out by keeping their interdisciplinary objectives but fruiting almost exclusively the expertise of sociologists.

The paradigm shift mediated the resumption of scientific collaboration with the West by the mid-1960s. On the one hand, Romanian specialists have begun to participate in scientific events abroad and benefit from scholarships and internships at major universities worldwide. On the other hand, an increasing number of sociology degrees were translated into Romanian, while Romanian university libraries made a real effort to expand their Western scientific literature collections. Such intellectual conversations allowed for profound reevaluations of the directions of social investigation. In a key remarkably close to the Western practice, the Romanian specialists showed some over-specialization tendencies within the discipline; already at the end of the 1960s, areas of expertise regarding urban sociology, youth sociology, labor sociology, etc., were outlined. However, openness to professional communities beyond the Iron Curtain would not have been possible without a favorable international context. As some researchers have recently shown, the intensification of scientific cooperation between the first and second worlds in the late 1960s and early 1970s cannot be read independently of convergence trends in political, economic, and cultural fields. More specifically, cooperation was a two-way street. Given the increasingly shared belief that industrialization produces similar social shifts everywhere, regardless of the political context in which they operate, Western communities of experts have often looked to Eastern European realities to understand their home countries' social dynamics better. This was also fostered by a revival of Marxism in many Western intellectual circles, which favored the shaping of a common intellectual ground where Western and socialist scholars shared a common conceptual language.

\section{The making of a scientific language}

In 1974, when Rueben Hill wrote to Miron Constantinescu to inquire about sociological activism types emerging under the Romanian socialist regime, the two were not strangers. While their first encounter circumstances are unclear, their professional relationship had a long history that went back to the early 1970s. Hill was a world-renowned specialist in family sociology who strongly advocated for transnational dialogue and cooperation between experts and decision-making factors for most of his academic career. Being involved in 
the activities of various international organizations, he coordinated more than forty research projects worldwide. A leftist since college, he was also known for his genuine interest in the non-Western world.

Furthermore, since the late 1960s, Hill regularly traveled in socialist bloc countries, aiming to set up new collaborative projects with Est-European social scientists and comprehend the local social realities. Such effort proved shortly advantageous. In September 1970, at the World Congress in Varna, Hill was elected president of the International Sociological Association (ISA) because of the support of socialist and third world countries' delegates. In the years to come, cooperation between Hill and Constantinescu further developed through the ISA channels. However, the effectiveness of their professional dialogue varied in time, reflecting at large not only the complicated process through which the socialist experts negotiated their international visibility but also the personal and informal facets that the trans-ideological scientific conversations often took. While Western experts shared a genuine interest in EastEuropean sociological output, seeing multiple possibilities to better comprehend social shifts in emerging industrial societies worldwide, the socialist bloc's ambiguous professional practices often complicated the transnational scientific cooperation. Moreover, knowledge exchange between West and East gained momentum only after socialist experts openly agreed to cooperate with capitalist social scientists.

The World Congress of Sociology in Varna offers an excellent glimpse of the ambivalence of this situation. In 1970, just weeks before the start of the Congress, Eastern European social scientists met to address the forthcoming event's final technical details. The official schedule was diverse, including research methodology, dissemination of results, or future collaborative projects. However, the most notable moment of the meeting was, no doubt, the Soviet representative's request that socialist participants would make a common front against what he called "the assault of the bourgeois sociology upon the socialist sociology." By making this claim, the Soviets echoed an ultra-conservative shift in international relations adopted by the Brezhnev regime in the aftermath of the Prague 1968 events. With the doctrine of non-intervention officially in place, the Soviets dived into a virulent discursive campaign that sparked old ideological tensions between East and West. Under the new circumstances, socialist states were expected to comply with the new regulations and appropriate various scientific thinking models (ANIC, fund ASSP Sociologie, file 1/1970, p. 37-38).

Nevertheless, this claim of the unity of the socialist bloc raised suspicion amongst the Romanian delegates. Just like two years before when Nicolae Ceausescu openly opposed the Soviet invasion of Czechoslovakia, in 1970, the 
Romanian experts rejected Soviet demands in favor of autonomous scientific international cooperation. Summarizing the discussions, sociologist Virgil Constantinescu warned that, by following the Soviets lead,

\begin{abstract}
we would leave the impression that there was a sociological bloc that went to meet another sociological bloc, which not only would be unreal, but it would not be useful for the success of the discussions, as it would start from some preconceived formulas and a priori elaborated schemes. (ANIC, fund ASSP Sociologie, file 1/1970, p. 37-38).
\end{abstract}

The Congress' sessions, nevertheless, placed the Soviets' request in a different light. Despite the massive participation of the socialist delegates, EastEuropeans were little successful in carrying out scientific conversations with Western experts, much less in demonstrating the usefulness of Marxism-Leninism in social research. On the contrary, the event unveiled the negative implications of too many years of isolation behind the Iron Curtain. In Osipov's words, the Soviet delegate, the Varna meeting had made it apparent that the Western sociological field was dominated by two theories: post-industrial society and modernization. While the socialist experts were familiarized with the first, being able to participate in the debates combatively, they lacked any knowledge about the second:

That is why this theory's basic principles fueled the discussions of bourgeois sociologists in those groups. As experience shows, sometimes, we are not aware of different orientations of bourgeois sociology, in general. We know some theories incompletely [...] and [only a very few Western] concrete field research. And then an objective difficulty arises. Without knowing these mid-level theories and [capitalist] empirical research, it is tough to evaluate them, to assess them. Thus, it happened that in some conference papers, [in] deliveries of our delegates, we made the theory of bourgeois sociological works that have been obsolete for 10-15 years, [which] have long been a thing of the past. (ANIC, fund ASSP - Sociologie, file 8/1971, p. 70-71).

Occurred in various intellectual contexts worldwide, such professional exchanges often led to the emergence of trans-national and trans-ideological networks to produce and circulate knowledge. Moreover, these new epistemic communities proved effective mediums for critical engagement with social research methodologies. They aggregated alternative scientific discourses about social change, which often eluded the nation-states' dominant ideologies. For the Romanian experts, these statements came in handy. Shortly after the Varna 
gathering, their effort to set up collaborative projects beyond the Iron Curtain gained momentum. Somewhat more pragmatic than initially estimated, Romanian specialists sought to aggregate a type of expertise that could have contributed to a better comprehension of the recent shifts in industrial communities worldwide. Particular attention was paid to the housing problem and industrial ventures' territorialization (AONU Geneva, box 2161). The Romanian social scientists began to attend periodically international events and undertake research stays at the most representative world universities, on the one hand. On the other, the national authorities financed comprehensive translation programs of the scientific literature. However, the intellectual mobilization that followed should not be read as the Eastern European champ's engagement into a doctrinal war with the West, and even less as an expression of the confrontation of "grand theories" (ANIC, fund ASSP - Sociologie, file 7/1976). On the contrary, it tellingly fleshes out how the Romanian social scientists complied with the Ceausescu regime's general policy of opening to the West and gradually articulated a new professional agenda independent from the Soviet models.

The International Sociological Association and the UN played a significant part in this process. The two organizations provided a friendly institutional environment where experts jointly chiseled a new scientific language (ANIC, fund ASSP - Sociologie, file 7/1976). ${ }^{3}$ For instance, several workshops organized in Washington, Geneva, Rome, Paris, or London brought together experts from both West and East to debate the interplay between city renewal and life quality improvement. Based on sophisticated analyzes of the social dynamics, experts made a case for new housing ownership regulations, stressing the importance of democratizing housing access. Another issue under consideration was the interplay between urban policies and population policies, labor-management, payment regulations, or policies toward vulnerable socio-professional categories such as young people, the elderly, women, and low-skilled staff. As one participant has put it, it was essential to see

how such rates, female labor, participation rates, the number of working hours per week, work and leisure ethics are inter-related among themselves and, at the same time, linked with the spatial patterns of economics and leisure time activities. (AONU Geneva, box 2161)

3 By the mid-1970s, there were numerous discussions about the establishment of Interconcept, a European data aggregation center that had to serve the needs of the UN in a first stage, and later of the entire scientific community. 
Subsequently, in the second half of the 1970s and early 1980s, a series of meetings held in various European locations brought together Eastern and Western specialists to translate scientific vocabulary into a set of social regulation techniques. For example, the meeting of planning experts, held in Budapest in 1981, discussed several agendas, each based on the participant states' particular modernization priorities. Western countries made a case for considering the social aspects of human settlements (Scandinavian countries) or urban areas (the Netherlands). Socialist countries have expressed interest in "the system of settlements, including questions of national and regional infrastructure, second homes, and settlement development for industrial purposes" (AONU Geneva, box 2161).

As a result of these contacts, transnational cooperation has become more comfortable as the years went by. The European Center for Coordination of Research and Documentation in the Social Sciences, which operated in Vienna between 1962 and 1972, also played an essential part in this process. Open to all nationalities, the center provided the Romanians with a unique opportunity to get involved in several critical projects: assessments of urban development strategies, research on the human-environment, or the cost of urban growth in the industrial world (ANIC, Fond ASSP Sociologie, 6/1970 and 7/1970). Such actions aimed to produce a type of knowledge relevant for comparative analyses in the sociology of development, industrialization, and urbanization by encouraging experts to analyze "socio-economic factors of growth, industries location, or cost urban growth" (ANIC, fund ASSP Sociologie, file 7/1970, p. 114).4

By the mid-1970s, the United Nations officially launched several actions by which the international scientific community could have gained access to information about the East-European social sciences' practices. In 1975, ECOSOC surveyed the national organization of the bureaucratic apparatus responsible for urban planning. Several European countries, including Romania, have sent detailed descriptions of the relevant institutional structures. The reports provided definitive information on the bureaucratic mechanisms at the national, regional, and local levels, the management system, funding sources, and the legislative framework underlying their functioning. Around the same time, a group

4 Or, in the words of Roman Moldovan, vice-president of the ASSP: "The Romanian researcher to be recommended is to deepen theoretical and methodological studies in the field of sociology of development, especially regarding the place and role of human resources in development, economic and social, the optimal conditions for the efficient training and capitalization of the labor force in accordance with the current and perspective requirements of the contemporary scientific-technical and social progress. He would carry out these studies in close correlation with the needs of the development and modernization of the industry." ANIC, fund ASSP - Sociologie, file 7/1970, p. 142. 
of researchers at the University of Illinois at Urbana Champaign proposed to the Ford Foundation a grant project that aimed to deliver a comparative analysis of the regional development strategies in capitalist (Great Britain, the Netherlands, and Italy) and a socialist (Romania) regimes. They aimed to aggregate data and then mobilized the European Economic Commission's financial and human resources to draw up long-term projects that would improve human settlements' quality of life worldwide (AONU Geneva, box 2058; AMAE, Problema 217/B CEPECA, file 3390/1973).

\section{A complicated reality}

In August 1968, when Nicolae Ceausescu announced to an enthusiastic crowd the Bucharest authorities' refusal to join Soviet troops in invading Czechoslovakia, Romania was perceived by the most international community as the rising star of the Socialist bloc. The first actions to assert Romania's autonomy from the Soviet Union were adopted as early as 1958 when socialist leaders formulated an economic development project based on intensive industrialization. Carried out against the USSR's approval, which had campaigned for the coordination of economic programs at the level of the socialist bloc and the development of the Romanian agrarian economy instead, the project aimed at expanding the infrastructure of heavy industry and intensifying urbanization. From a social point of view, the program has contributed to increasing most Romanians' living standards. From a political point of view, the authorities' decision had proved effective in exploiting the general anti-Soviet feeling of the population and converting it into a capital of unprecedented legitimacy. In this regard, by taking this path in 1968, the national leaders aimed to strengthen political and economic bridges with the West as a precondition for further scientific and cultural cooperation beyond the Iron Curtain. In this way, Romania would have secured its access to the latest technologies necessary for industrial development and improved living standard. However, there were also pragmatic arguments at stake. At the time, it became increasingly clear that due to recent years' political and economic global shifts, the Iron Curtain's permeability increased in many ways, which pressured the national decision-making factors to align the regime's redistribution agenda with growing consumer expectations (Cooper, 2010: 44-64; Ban, 2014; Granick, 1975; Hohmann, 1982).

By the late 1960s, the national leaders' main challenge was articulating a new country project without questioning the regime's socialist nature. The CC Plenary of the Romanian Communist Party in June 1968 openly addressed the 
issue of affordable housing. In his concluding speech, Nicolae Ceaușescu made a case for reconsidering the housing policies to double the number of finished units in the next decade. More measures followed. After debating the issue during several meetings at the highest level of the state's leadership, Nicolae Ceausescu outlined the future development program's main directions in September 1969 during the 10th Congress of the Romanian Communist Party. Accordingly, the country's leader announced its intention to make massive investments in industrialization and urbanization. In doing so, Ceausescu did not back up his statement with any information that could have illuminated the audience about costs and long-term financial implications, nor did he draft a schedule for the measures' implementation. Instead, he argued that Romania was on the verge of becoming a "multilaterally developed socialist society," making it mandatory to take consistent measures towards successfully diminishing development disparities between rural and urban areas shortly. Meeting such goals meant expanding transport infrastructure, improving housing stock, and modernizing lifestyle (Ceaușescu, 1972).

In many ways, such an agenda was justified. Despite significant investments since the early 1950 s, Romania had remained a predominantly underdeveloped economy, with more than $70 \%$ of the labor force employed in agriculture. Even so, the level of territorial modernization was uneven. Post-war growth was evident in those areas with a strong industrial tradition since the interwar period. Simultaneously, many rural populations continued to live in precarious conditions (Murgescu, 2010).

However, the Romanian authorities' immediate challenge was hardly about building new factories and modernizing existing urban infrastructures. Much more pressing was the need to comprehend industrialization's social transformations better and, implicitly, convert this type of knowledge into sustainable medium and long-term development projects. Research conducted by the Center for the Study of Youth Problems and the Laboratory of Urban Research of the University of Bucharest by the late 1960s had already unveiled numerous individualization instances within most industrial communities. Due to internal migration, lack of appropriate housing facilities, and increasing daily commuting rates in inappropriate conditions, many of the workforces faced severe difficulties in integrating themselves into the new working environments. According to the official statistics, workers tended to change their workplace periodically, sometimes moving from one locality to another; moreover, their unpredictable professional behavior severely impacted labor productivity and social cohesion (Bădina, 1969; Bădina, 1971; Bădina, 1973; Bădina, 1975). In this respect, it was becoming increasingly clear that there was an organic interdependence between 
labor force management and the development of industrial, urban, and transport infrastructure. At the intersection of these plans, the multilaterally developed socialist society project implied foremost articulating a new spatial vision.

The administrative reform of 1968 was the first step in this direction (Stahl, 1969). As was the case with other legislative regulations, the initiative also had strong ideological connotations. The governmental act decided to abandon the administrative system implemented at the end of World War II after the Soviet model (a three-level hierarchical system consisting of regions, districts, and communes) and return to the interwar system consisting of smaller counties, municipalities, and communes. The reorganization aimed at streamlining the decision-making process between the center and the less developed territories; it also aimed at a rational organization of territorial functions through decentralization and local resources mobilization. In drawing up the new national map, decision-makers considered an older administrative tradition and the location of economic objectives and their social infrastructure, the expansion of the transport network, the area of influence of cities on metropolitan areas, or the state's role in this project.

However, a closer look at the main ideas framing the territorial reorganization not only traces numerous similarities with Cincinat Sfintescu's interwar ideas but places Romanian leaders' objectives in conversation with international debates on the concept of regional planning. Originally formulated in the Resolution of the Economic and Social Council of the United Nations General Assembly in 1965, the term referred to cities' impact on the expansion and modernization of metropolitan areas of urban agglomerations. It served as a theoretical umbrella for the international expert community's current efforts to draw territorialization models sensitive to social dynamics worldwide (Ellman, 2014).

\section{Systematization as a social project}

Despite the decision-making factors' commitment to reconceptualize long-term national urban planning strategies, the early 1970s developments had caused much confusion amongst the Romanian sociologists. Their reservations were fueled by inherent difficulties in translating Western ideas into hands-on national public policies on the one hand, and, on the other, by their limited experience in setting up collaborative actions with experts from outside their profession. 
Of course, there were numerous opportunities for expanding scientific cooperation beyond the Iron Curtain in domains like architecture, urban planning, sociology, or demography. Nevertheless, finding common ground at home so that local practitioners would join their efforts and elaborate complex development strategies proved to be a much more difficult task than one could have initially expected. This situation was the outcome of decades-long professional adaptations to central planning mechanisms. Constraint to adapt to all sorts of shortcomings caused by the limited access to resources and pressures from decision-making factors, the Romanian technocracy developed alternative paths to preserve its status and professional autonomy (Verdery, 1996). To this end, guild solidarities took many forms, sometimes leading to questionable responses to other professions' attempts to penetrate their domains of expertise. For instance, in an article published in the journal Arhitectura RSR, Gheorghe Chepeș argued that sociologists should not get involved in urban planning since they lacked any knowledge. Moreover, any responsibility should be left with architects and urban planners (Chepeș, 1971: 57).

In response to the current situation, the Romanian leaders tried to develop a knowledge infrastructure that could have facilitated inter- and transdisciplinary cooperation. The newly established Academy of Social and Political Sciences (ASSP) and the Center for Urban Research of the University of Bucharest were probably the first attempts. Designed to serve as a laboratory of social research in urban areas, the organizations aimed to fructify the advantages of the recent re-institutionalization of sociology and mobilize architects, urban planners, and social scientists to comprehend the current social trends better. However, despite good intentions, the process proved lengthy and complicated.

On 10 December 1971, the Academy of Social and Political Sciences initiative to organize in Iasi a debate on the urban sociological area's concept aimed to bring some welcome clarifications in this regard. Led by Henry Stahl, the Sociology Section president, the meeting was held under Miron Constantinescu's patronage. It brought face to face social scientists, urban planners, national and local decision-makers, and party leaders. While such gatherings have been organized many times before, what was exceptional about the Iasi meeting was its agenda. It revolved around two main issues: social scientists' professionalization and social research methodologies in urban areas. Moreover, unlike regular political debates on governmental regulations of urban growth, the Iasi meeting aimed mainly to increase the social sciences knowledge' visibility in the socialist state's developmental project.

In his opening remarks, Stahl abruptly stated that "library sociologists" that is, those researchers who had invested much time in mastering the "general theories" of foreign social sciences without carrying out a consistent field investigation, were rather unhelpful to the socialist state's new agenda. However, Stahl 
was far from rejecting any cooperation with Western experts. On the contrary, well connected to the international scientific community, he was perfectly aware of his colleagues' professional limitations (Rostas, 2000). Suggestive in this regard was his remark that "any foreigner who has [access to] a good library works better than we do" (ANIC, fund ASSP - Sociologie, file 20/1971, f. 47). The problem, in his view, was the inability of the local specialists to convey the massive amount of Western theoretical knowledge into valid models of interpretation of the Romanian realities and then to aggregate statistical series on demographic dynamics, labor market opportunities, housing stock, industrial prospects, or transport infrastructure into effective public policies (ANIC, fund ASSP - Sociologie, file 20/1971). Accordingly, it became essential to train professionals in "a spirit of deep intuition" of the social transformation, which would help experts make the most of the informational potential accessible through various professional channels and convert knowledge into national modernization strategies. Put merely, Stahl made a case for a return to empirical research, a view that echoed his life-long commitment to concrete field investigations. He also argued that local scientists consider research methods previously developed by Western experts when building several European urban databases so that Romanian outputs gain international relevance (ANIC, fund ASSP - Sociologie, file 21/1971).

Proof of his intellectual scope, the idea that local research may contribute to a broader social research agenda raised questions about the 1970s Romanian experience's exceptionality when the international experts' community considered territorial development issues. This principle was further developed during the Iasi meeting through a complicated analysis of the sociological area concept (Petrovici, 2017). First formulated during the research campaign on urbanization in the Slatina region, the term referred to

... realities and territorial units, with specific economic and social characteristics, [...] and to the interconnection between all these features and elements within an area, their interdependence, and interaction. (Constantinescu, 1971: 144).

At the time, researchers aimed to assess the relationship between "underdeveloped", "superiorly developed", "stagnant", or "expanding" urban areas. Despite encouraging results, the research campaign in Slatina had opened more questions than provided answers.

In Iasi, Stahl resumed the discussion on the concept. In his address, he problematized possible similitudes between Romanian and Western views. He stated that large cities began to influence the surrounding area due to the previous years' industrialization programs, delimiting various interconnections 
between the urban core and its rural perimeter, the so-called hinterland. The new "territorial communities," which emerged at the crossing of labor, food, and raw materials supply networks, would have been characterized by their members' specific lifestyle.

One exciting point belonged to Alexandru Bărbat, professor of sociology at the University of Iași. He began by expressing his reservations about the opportunity of differentiating between urban and rural areas when new visions of the social were at stake. Based on Iasi's example, an old university center with a robust industrial infrastructure, he argued that the large urban cores' cultural and social influence usually was perceivable in a nearby rural area and even in an entire region. Moreover, new "feelings, states, systems or patterns of social life" (ANIC, fund ASSP Sociologie, file 20/1971, p. 14.) would emerge at a smaller or greater distance from the urban core. Instead of focusing on the urban nucleus, Bărbat suggested consistent modernizing rural projects, ensuring an improved daily experience compared to the "tiring urban" of the big industrial cities. Resumed in a text published in the first issue of the review Viitorul social, Bărbat's arguments were much more far-reaching than one might first think. More concretely, by paying particular attention to economic decentralization, rural industrialization, or the labor force's flexibilization Bărbat seemed much more concerned with what Rose tellingly defined as "the congruence between the needs of the worker and the needs of the industry." Such ideas were remarkably like the UN vocabulary. Moreover, the international organization

recommended defining urban agglomeration and any other communal unit as [...] a distinct and indivisible population group (called agglomeration, place of residence, center of population, group, etc.), whatever its size, having a recognized name or status and functioning as an integrated social entity. (ANIC, fund ASSP - Sociologie, file 16/1976, p. 29).

In Jiri Musil's terms, socialist urbanization evolved in two main directions, both articulated around the idea of central planning. The first was based on central place theory; it consisted of horizontal development of the localities' network and population's even access to services and social infrastructure. The second, built on polarization theory, proposed a concentration of financial allocations in designated urban nuclei strategically located in areas critical for the national development project (Musil, 1980: 14). In absolute terms, the urbanization processes in Romania followed the lead of the second strategy. However, there was a short interlude in the first half of the 1970s when elements specific to the first strategy surfaced in the urban planning solutions. Accordingly, as this article shows, this shift occurred due to an emerging field of social research 
expertise that fructified the global production and circulation of knowledge and was very much indebted to the growing visibility of social scientists in the domestic decision-making processes on urban growth strategies. Such developments are best visible in the Academy of Social and Political Sciences activity in the field of urban planning. Minutes of various meetings held with the broad participation of the decision-making factors addressed urban life and city renewal issues and aimed to sketch feasible strategies of growth. Furthermore, minutes of the Architects Union's early 1970s meetings flesh out bemusement when the political decision-making factors requested hands-on solutions on the central issues at stake. However, this joint involvement of the social scientists and urban planners played a central part in sketching the first version of the national systematization plan.

In 1972, the National Systematization Plan's first draft was adopted at the National Conference of the Romanian Communist Party. Building on the Iasi debate's conclusions, the program aimed to develop the national network of localities, foster trans-regional coordination between industrial and social objectives, organize regional leisure areas, and territorialize economic units based on environmental principles. One of this legislative package's main features was its focus on stimulating labor mobility from the primary to the secondary and tertiary sectors. Such shifts, however, would occur without stimulating ruralurban migration and population concentration in large urban agglomerations. From a theoretical standpoint, the concept of systematization referred to the action of "planning social development" and stimulating "the regenerative function of the countryside." A series of articles later published in the journal Arhitectura RSR detailed the basic principles. Scientifically based, the 1972 territorial systematization program described cities as flexible spatial units capable of responding to present and future social needs. Rural areas, in turn, were to polarize economic and social activities independently of large urban centers. The connection between the various human conglomerates was to be ensured by modernizing the communications network and implementing a coherent strategy to stimulate people and goods' movement.

Under the new legislative conditions, significant changes occurred in the specialist's training as well. Since higher education social sciences programs were still in their infancy, training was conducted on alternative channels. Romanian experts' access to Western knowledge was instrumented through the Center for Training the Industrial Managers (CEPECA). Heavily financed by the UN and benefitting from the experience of a cohort of Western, mostly British, experts, CEPECA offered courses in critical areas such as spatial planning, cybernetics, statistical modeling, or forecasting. Beginning with 1973, specialists 
involved in urban planning undertook regular training sessions at CEPECA, the center providing an excellent framework for converting transnational knowledge into national policy-making programs (ANIC, fond ASSP Sociologie, file 21/1971, p. 29). Equally important, the UN Regional Economic Commission provided training programs for Eastern European experts. Intra-regional knowledge exchanges between countries facing similar problems was thought to build bridges between national and international epistemic communities (AONU Geneva, box 2158).

These initiatives have been fruitful. Between 1972 and the early 1980s, the Romanian experts regularly participated in international meetings on territorial planning issues. For instance, Miron Constantinescu attended several ISA meetings. There he presented in detail the concept of sociological area and the presumptive part played by social scientists in carrying out these goals. At his suggestion, AIS established an International Committee on Researching the Sociological Areas. Hence Hill's interest in sociologists' activism in the context of the 1975 Eighth World Congress of Sociology.

The transnational professional dialogue's intensification should have forced national authorities to adopt reforms and change governance principles. In Harvey's words,

the tension between the inflexibility imposed by state regulations and the smooth movement of capital flows ... could be modified by how the state itself allows itself to be disciplined by internal forces and external conditions such as the world economy, exchange rates, capital movement, migration, etc. (Harvey, 1991: 109)

In Romania's case, the events of the 1970s showed that the state was unwilling to give up the regulation of planning as an eminently domestic policy. For a while, urban planning has acted as a vector of mediation between the inflexibility of the decision-making apparatus and the centrifugal forces of sociologists concerned with adjusting the practice of medium- and long-term planning so that national plans recognize and respond effectively to specific global social changes. However, this reality was far from linear, somewhat fragmented, and influenced by what the elites found necessary to legitimize them.

\section{ARCHIVES SOURCES}

United Nations Archives, Geneva (AONU Geneva), box 2058; 2158; 2161.

National Archives of Romania, Bucharest (ANIC), Fund ASSP - Sociologie, files 1/1970; 6/1970; 7/1970; 8/1971; 20/1971; 21/1971; 25/1971; 7/1976; 16/1976. Ministry of the Exterior Archives, Bucharest (AMAE), Problema 217/B CEPECA, file 3390/1973. 
EPISTEMIC ENCOUNTERS: SOCIAL SCIENCES AND THE RETHINKING OF URBAN PLANNING POLICIES

IN THE EARLY 1970S ROMANIA

\section{REFERENCES}

Bădina, Ovidiu (1970). Tineret rural 68. [Rural youth 68]. Bucharest: Editura Academiei RSR.

Bădina, Ovidiu (1972). Tineret rural: Participare și acțiune socială. [Rural youth: Participation and social action]. Bucharest: Editura Academiei RSR.

Bădina, Ovidiu (ed.) (1975). Tineretul și societatea noastră socialistă. [Our youth and our socialist society]. Buchrest: Editura Academiei RSR.

Ban, Cornel (2014). Dependență și dezvoltare: O economie politică a capitalismului românesc. [Dependence and development: A political economy of Romanian capitalism]. Cluj-Napoca: Tact.

Bosomitu, Stefan (2015). Miron Constantinescu. O bibliografie. [Miron Constantinescu. A bibliography]. Bucuresti: Humanitas.

Ceaușescu, Nicolae (1972). România pe drumul construirii societății socialiste multilateral dezvoltate. Rapoarte, cuvântări, articole. Mai 1971-februarie 1972. [Romania on the road to building a multilaterally developed socialist society. Reports, speeches, articles. May 1971-February 1972]. Bucuresti: Editura Politică.

Chepeș, Gheorghe (1971). Reflecții ale unui sociolog pe marginea sistematizării ca disciplină și acțiune. [Reflections of a sociologist on systematization as a discipline and action]. Arhitectura RSR [Architectura SRS], 1: 57.

Christian, Michael, Sandrine Kott, Ondřej Matějka (ed) (2018). Planning in Cold War Europe. Competition, Cooperation, Circulations (1950s-1970s). Berlin: De Gruyter.

Constantinescu, Miron (1971). Cercetări sociologice, 1938-1971. [Sociological research, 1938-1971]. București: Editura Academiei RSR.

Cooper, Richard N. (2010). Economic aspects of the Cold War, 1962-1975. In The Cambridge History of the Cold War, vol. II, Crises and Detente, ed. Melvyn P. Leffler and Odd Arne Westad. Cambridge: Cambridge University Press.

Cotoi, Calin (2011). Sociology and Ethnology in Romania: The Avatars of Social Sciences in Socialist Romania. In Sociology and Ethnography in East-Central and South East Europe: Scientific Self-Description in State Socialist Countries, ed. Ulf Brunnbauer, Claudia Kraft et al. Munchen: Oldenbourg Verlag.

Dobos, Corina (2020). Between Statistics, Demography, and Monographic Research: GH. Retegan (1916-1998), A(nother) Sociologist Without A Sociology. Studia UBB Sociologia, 65 (LXV), 1: 5-42.

Ellman, Michael (2014). Socialist Planning. Cambridge: Cambridge University Press.

Ferguson, Niall, Charles S. Maiers, Erez Manela and Daniel J. Sargent (ed.) (2010). The Schock of the Global: The 1970s in Perspective. Cambridge Mas: The Belknap Press of Harvard University Press, 2010.

Granick, David (1975). Enterprise Guidance in Eastern Europe. A Comparison of Four Socialist Economies. Princeton: Princeton University Press.

Guga, Stefan (2015). Sociologia istorică a lui Henry Stahl. [The historical sociology of Henry Stahl]. Cluj-Napoca: Tact. 
Harvey, David (1991). The Condition of Postmodernity: An Enquiry into the Origins of Cultural Change. Cambridge MA \& Oxford: BLACKWELL.

Hâncu, Adela and Viktor Karady (ed.) (2018). Social Sciences in the "Other Europe" since 1945. Budapest: CEU Press.

Hohmann, Hans-Herman (1982). Economic reform in the 1970s - policy with no alternative. In The East European Economies in the 1970s, ed. Alec Nove, Hans-Hermann Hohmann and Gertraud Seidenstecher. London: Butterworth \& Co.

Iriye, Akira, Petra Goedde and William I. Hitchcock (2012). The Human Rights Revolution: An International History. Oxford: Oxford University Press.

Jolly, Richard, Louis Emmerij, Dharam Ghai, and Frédéric Lapeyre (2004). UN Contributions to Development Thinking and Practice. Bloomington, Indianapolis: Indiana University Press.

Marginean, Mara (2015). Ferestre spre furnalul rosu: Urbanism și cotidian în Hunedoara și Călan, 1945-1968. [Windows to the red furnace: Urbanism and everyday life in Hunedoara and Călan, 1945-1968]. Iasi: Polirom.

Mark, James, Bogdan C. Iacob, Tobias Rupprecht and Ljubica Spaskovska (ed.) (2019). 1989. A Global History of Eastern Europe. Cambridge: Cambridge University Press.

Murgescu, Bogdan (2010). România și Europa: Acumularea decalajelor economice. [Romania and Europe: Accumulation of economic gaps]. Iași: Polirom.

Murphy, Craig N. (2006). The United Nations Development Programme. A Better Way?. Cambridge: Cambridge University Press.

Petrovici, Norbert (2017). The Politics of Mobilizing Local Resources for Growth: 'Urban Areas' in Romania. Studia UBB Sociologia, 62 (LXII), 1: 37-64.

Platt, Jenifer and Immanuel Wallerstein (1998). A brief History of ISA: 1948-1997. Madrid: International Sociological Association.

Pula, Besnik (2018). Globalization Under and After Socialism. The Evolution of Transnational Capital in Central and Eastern Europe. Stanford: Stanford University Press.

Romano, Angela and Federico Romero (ed.) (2021). European Socialist Regimes' Fateful Engagement with the West. National Strategies in the Long 1970s. Abington, New York: Routledge.

Rubinson, Paul (2012). «For our Soviet colleagues»: Scientific Internationalism, Human Rights, and the Cold War. In The Human Rights Revolution. An International History, ed. Akira Iriye, Petra Goedde, and William I. Hitchcock. Oxford: Oxford University Press, 2012.

Solovey, Mark and Hamilton Cravens (ed.) (2012). Cold War Social Science: Knowledge Production, Liberal Democracy, and Human Nature. New York: Palgrave.

Stahl H. H. (1969). Organizarea administrativ-teritorială. [Administrative-territorial organization]. Bucharest: Editura Știintifică.

Rostas, Zoltan (2000). Monografia ca utopie: interviuri cu Henri H. Stahl (1985-1987). [Monograph as a utopia: interviews with Henri H. Stahl (1985-1987)]. Bucharest: Padeia.

Verdery, Katherine (1996). What was socialism and what comes next? Princeton: Princeton University Press.

Zamfir, Cătălin, and Iancu Filipescu (ed.) (2015). Sociologia românească: 1900-2010: O istorie socială. [Romanian sociology: 1900-2010: A social history]. Cluj-Napoca: Eikon. 